Al-Tarbawi Al-Haditsah: Jurnal Pendidikan Islam

Vol. 3, No. 2, Desember 2018

\title{
IMPLEMENTASI PENDIDIKAN AGAMA ISLAM (PAI) BERWAWASAN LINGKUNGAN DI SEKOLAH MENENGAH KEJURUAN NEGERI I INDRAMAYU
}

\author{
Eha Julaeha \\ SMKN 1 Sindang Indramayu \\ ehaslamet74@gmail.com \\ Asep Kurniawan \\ Menejemen Pendidikan Islam FITK IAIN Syekh Nurjati Cirebon \\ Asep.kurniawan@syekhnurjati.ac.id
}

\begin{abstract}
Abstrak
Penelitian ini dilatarbelakangi oleh maraknya kerusakan lingkungan, banyaknya terjadi bencana alam yang merupakan ancaman yang membahayakan untuk makhluk di muka bumi ini. Oleh sebab itu sangat penting adanya pendidikan berwawasan lingkungan yang diintegrasikan melalui pengelolaan pembelajaran pada semua mata pelajaran tak terkecuali mata pelajaran Pendidikan Agama Islam di lingkungan pendidikan formal untuk membentuk karakter peserta didik sebagai generasi yang sadar akan lingkungan hidup serta untuk menjaga kelestarian alam. Penelitian ini bertujuan mendeskripsikan secara mendalam mengenai implementasi pembelajaran Pendidikan Agama Islam (PAI) berwawasan lingkungan hidup di SMK Negeri 1 Indramayu Kabupaten Indramayu. Jenis penelitian ini adalah penelitian lapangan (field research) dengan pendekatan kualitatif. Pengumpulan data penulis lakukan dengan menggunakan metode wawancara, observasi dan studi dokumentasi. Sedangkan untuk analisisnya, penulis menggunakan teknik analisis deskriptif kualitatif, yaitu berupa data-data yang tertulis dan perilaku yang diamati sehingga dalam hal ini penulis berupaya mengadakan penelitian yang bersifat menggambarkan secara menyeluruh tentang keadaan yang sebenarnya.
\end{abstract}

Kunci Kata: Kerusakan lingkungan, Integrasi, Internalisasi, Kepedulian

\begin{abstract}
This research was motivated by the widespread destruction of the environment, there were many natural disasters that pose a dangerous threat to creatures on this earth. Therefore, it was very important to have environment-based education, which was integrated to learning management in all subjects. It included the subject of Islamic Education in the formal education to shape students' character to preserve environment. This study aimed to describe the implementation of environment-based islamic religious education in State Vocational School 1 Indramayu. This was a field qualitative research. Data collection conducted through in-depht interviews, in-depht observation and documentation. Data
\end{abstract}




\section{Al-Tarbawi Al-Haditsah: Jurnal Pendidikan Islam}

Vol. 3, No. 2, Desember 2018

analysis was qualitative descriptive analysis. Research findings: management policy of environment-based islamic learning in State Vocational School Indramayu 1 was implemented in accordance with the Adiwiyata School Standard Operating Procedure. Its management made students' learning activities friendly to the environment. Its implementation by applying it in everyday life. Supporting factors for this program were adequate school facilities and establishment of synergy of all stakeholders in realizing environment-based islamic religious learning. The inhibiting factor was the limited learning time of Islamic Education.

Key Words: Environmental Degradation, Integration, Internalization, Concern

\section{A. Pendahuluan}

Seiring berakhirnya abad ke-20, masalah lingkungan menjadi salah satu pembahasan yang paling utama dan signifikan untuk didiskusikan. Persoalan ini dilatarbelakangi oleh serangkaian masalah-masalah global yang membahayakan biosfer dan kehidupan umat manusia dalam bentuk yang demikian membahayakan bahkan sangat memungkinkan, jika dalam waktu relatif singkat akan menjadi fenomena yang tidak dapat dikembalikan lagi, sehingga secara cepat kehancuran bumi akan terjadi. ${ }^{1}$

Masalah lingkungan dewasa ini, memang banyak menuai perhatian masyarakat dunia, karena pada kenyataannya alam dari hari ke hari kian kritis, terjadi degradasi lingkungan ${ }^{2}$ di sana-sini. Hutan yang mensuplai

\footnotetext{
${ }^{1}$ M. Thalhah dan Achmad Mufid A.R. Fiqih Ekologi; Menjaga Bumi Memahami Makna Kitab Suci. (Yogyakarta: Total Media, 2008), h. xi

${ }^{2}$ Degradasi lingkungan adalah kerusakan lingkungan melalui penipisan sumber daya seperti udara, air dan tanah; penghancuran ekosistem; perusakan habitat; kepunahan satwa liar; dan polusi. Ini didefinisikan sebagai perubahan atau gangguan terhadap lingkungan yang dianggap merusak atau tidak diinginkan. Johnson, D.L., S.H. Ambrose, T.J. Bassett, M.L. Bowen, D.E. Crummey, J.S. Isaacson, D.N. Johnson, P. Lamb, M. Saul, and A.E. Winter-Nelson. 1997. "Meanings of environmental terms", dalam Journal of Environmental Quality, 26: 581-589. Degradasi lingkungan disebabkan oleh kombinasi populasi manusia yang sudah sangat besar dan meningkat, pertumbuhan ekonomi yang terus meningkat atau kemakmuran per kapita, dan penerapan teknologi yang merusak lingkungan. Lihat Chertow, M.R., "The IPAT Equation and its Variants", dalam Journal of Industrial Ecology, 4 (4) 2001:13-29. Huesemann, Michael H., and Joyce A. Huesemann. "Technofix: Why Technology Won't Save Us or the Environment", dalam Chapter 6, "Sustainability or Collapse?" (New Society Publishers, 2011). PBB mendefinisikan degradasi lingkungan sebagai pengurangan kapasitas lingkungan untuk memenuhi tujuan dan kebutuhan sosial dan ekologi. Lihat United Nations General Assembly. "Report of the Open-Ended Intergovernmental Expert Working Group on Indicators and Terminology Relating to Disaster
} 
oksigen kian menciut, air laut dan air sungai tercemar, tanah terkontaminasi dengan zat-zat yang berbahaya, lapisan ozon semakin menipis, perubahan iklim dan naiknya suhu bumi sehingga mengakibatkan gumpalan gunung es di Kutub Utara dan Kutub Selatan mencuat dan menyebabkan naik ke permukaan air laut. ${ }^{3}$ Kerusakan lingkungan ini adalah ancaman yang sangat serius secara resmi diperingatkan oleh Perserikatan Bangsa-Bangsa.

Pada masa kehidupan modern ini, manusia dituntut untuk berkembang dan semakin maju. Akan tetapi, dengan meningkatnya kemajuan teknologi dan taraf hidup ini, mengakibatkan timbulnya persoalan-persoalan yang semakin meningkat, terutama masalah lingkungan. "Persoalan lingkungan semakin lama semakin kompleks. Persoalan yang muncul tidak hanya tentang lingkungan hidup dari aspek alamnya, tetapi juga pada aspek sosial-ekonomi yang terkait dengan dampak kerusakan lingkungan hidup."4 Seperti pencemaran air dan semakin berkurangnya pasokan air ${ }^{5}$, pencemaran sungai, pencemaran udara, kebakaran hutan, pencurian kayu, kerusakan terumbu karang, pencemaran pesisir dan laut, perdagangan satwa liar, banjir, longsor,

Risk Reduction", dalam Sustainable Development: Disaster Risk Reduction. Seventy-first session. 1 December 2016.

${ }^{3}$ Nadjamudin Ramli. Islam Ramah Lingkungan, Konsep dan Strategi Islam dalam Pengelolaan, Pemeliharaan, dan Penyelamatan Lingkungan. (Jakarta: Grafindo Khazanah Ilmu, 2007), h. 17. Suhu musim dingin yang lebih hangat menyebabkan penurunan snowpack, yang dapat menyebabkan berkurangnya sumber daya air selama musim panas. Hal ini terutama penting pada pertengahan garis lintang dan di daerah pegunungan yang bergantung pada limpasan glasial untuk mengisi kembali sistem sungai dan pasokan air tanah, membuat wilayah ini semakin rentan terhadap kekurangan air dari waktu ke waktu; peningkatan suhu awalnya akan menghasilkan peningkatan cepat pencairan air dari gletser di musim panas, diikuti oleh retakan di gletser dan penurunan pencairan dan akibatnya suplai air setiap tahun karena ukuran gletser ini semakin mengecil. Kenaikan suhu dapat mengurangi musim salju di musim dingin dan meningkatkan intensitas salju yang mencair yang menyebabkan limpasan puncak ini, mempengaruhi kelembaban tanah, banjir dan risiko kekeringan, dan kapasitas penyimpanan tergantung pada daerah tersebut. Lihat Ragab, Ragab, and Christel Prudhomme. "Soil and Water: Climate Change and Water Resources Management in Arid and Semi-Arid Regions: Prospective Challenges for the 21st Century", dalam Biosystems Engineering. 81.1 (2002): 3-34; MacDonald, Glen M. "Water, Climate Change, and Sustainability in the Southwest”. PNAS 107.50 (2010): 56-62

${ }^{4}$ Rahchmad K. Dwi Susilo. Sosiologi Lingkungan dan Sumber Daya Alam. (Yogyakarta: Ar-Ruzz Media, 2012), h. 3.

${ }^{5}$ ilman, David, Joseph Fargione, Brian Wolff, Carla D'Antonio, Andrew Dobson, Robert Howarth, David Scindler, William Schlesinger, Danielle Simberloff, and Deborah Swackhamer. "Forecasting Agriculturally Driven Global Environmental Change", dalam Science 292.5515 (2011): 281-84. 


\section{Al-Tarbawi Al-Haditsah: Jurnal Pendidikan Islam}

Vol. 3, No. 2, Desember 2018

dan lain sebagainya. Ini semuanya adalah dampak yang harus dibayar sangat mahal dari terabaikannya aspek lingkungan hidup dalam keseluruhan proses pembangunan lingkungan. Ini belum termasuk gangguan penyakit dan menurunnya kualitas kehidupan manusia akibat kerusakan dan pencemaran lingkungan hidup. Al-Quran sudah memperingatkan bahwa kerusakan alam dan lingkungan diakibatkan oleh ulah tangan manusia ${ }^{6}$.

Ayat tersebut menunjukkan bahwa Islam sangat memperhatikan kelestarian lingkungan hidup. Karena, lingkungan hidup yang lestari akan memberikan kesejahteraan bagi generasi yang akan datang. Manusia sebagai khalifah di bumi diberikan wewenang membangun, melestarikan, dan memakmurkan alam dan lingkungan. Oleh karena itu Allahlah yang memberikan amanah. Hal ini berarti dapat dipahami bahwa dasar etika ekologi Islam benar-benar terletak pada gagasan al-Qur'an tentang khalifah dan amanah. Alam yang dimiliki Tuhan diberikan kepada manusia sematamata hanya sebagai amanah.

Kapasitas alam sebagai amanah yang mesti dijaga oleh manusia tentu jangan sampai rusak apalagi hancur karena ulah tanganmanusia itu sendiri. Sebagaimana dikatakan oleh Fachruddin Mangunjaya bahwa indikasi penyebab kerusakan, kehancuran, dan krisis lingkungan adalah mengenai perspektif manusia dan alam semesta pada era modern. Perspektif tersebut mengakibatkan semua unsur filsafat, budaya, dan kerangka spiritual, dapat mengurangi tingkat kebenaran dan membatasi ruang lingkup kognisi (pengenalan) dan eksistensinya hanya pada sensasionalnya dan segala sesuatu yang bersifat material. ${ }^{7}$

Selaras dengan yang disampaikan oleh Emil Salim sebagaimana dikutip Siahaan: "Manusia kini memiliki kemampuan menguasai alam, mampu mengubah, mengatur, dan mengelola lingkungan sesuai dengan

\footnotetext{
${ }^{6}$ Al-Qur'an Surat al-Ruum [30] Ayat 41.

${ }^{7}$ Fachrudin M. Mangunwijaya, Husain Heriyanto, Reza Gholami. Menanam sebelum Kiama: Islam, Ekologi, dan Gerakan Lingkungan Hidup. (Jakarta: Yayasan Obor Indonesia, 2007), h. 25.
} 
kehendaknya." ${ }^{\prime 8}$ Hal yang sama diulas oleh Sayyed Hossein Nasr: "Krisis lingkungan bisa dikatakan disebabkan oleh penolakan manusia untuk melihat bahwa Tuhan yang menggenggam lingkungan yang nyata, yang mengelilingi manusia dan memelihara kehidupannya." ${ }^{9}$ Keutuhan lingkungan akan sangat bergantung pada kesadaran manusia dalam menjaganya. Ulah atau perilaku manusia dan pandangan manusia tentang alam sekitar termasuk lingkungan akan berdampak pada eksistensi lingkungan tersebut. ${ }^{10}$

Pemanfaatan alam yang dilakukan olehmanusia secara berlebihan akan merusak dan berdampak negatif pada keseimbangan alam. Kerusakan lingkungan merupakan akibat dari upaya manusia modern dalam memandang lingkungan alam sebagai tatanan realitas yang secara ontologi berdiri sendiri, terpisah dari lingkungan Ilahi. Padahal tanpa kekuasaan-Nya lingkungan menjadi sekarat dan mati."11

\footnotetext{
${ }^{8}$ Sihaan, NHT. Hutan, Lingkungan, dan Paradigma Pembangunan. (Jakarta: Pancuran Alam, 2007), h. 32.

${ }^{9}$ Sayyed Hossein Nasr. Islam dan Nestapa Manusia Modern. (Bandung: Pustaka Setia, 2001), h. 41.

${ }^{10}$ Dampak manusia terhadap lingkungan atau dampak antropogenik terhadap lingkungan termasuk perubahan pada lingkungan biofisik dan ekosistem, keanekaragaman hayati, dan sumber daya alam yang disebabkan secara langsung atau tidak langsung oleh manusia, termasuk pemanasan global, degradasi lingkungan (seperti pengasaman laut), kepunahan massal dan hilangnya keanekaragaman hayati, krisis ekologis, dan kehancuran ekologis. Memodifikasi lingkungan agar sesuai dengan kebutuhan masyarakat menyebabkan efek yang parah, yang menjadi lebih buruk karena masalah kelebihan populasi manusia terus berlanjut. Beberapa kegiatan manusia yang menyebabkan kerusakan (baik secara langsung maupun tidak langsung) terhadap lingkungan pada skala global termasuk reproduksi manusia, konsumsi berlebihan, eksploitasi berlebihan, polusi, dan penggundulan hutan, untuk menyebutkan beberapa. Beberapa masalah, termasuk pemanasan global dan hilangnya keanekaragaman hayati menimbulkan risiko eksistensial bagi ras manusia, dan kelebihan populasi menyebabkan masalah tersebut. Lihat U.S. Global Change Research Program. "Highlights of the Findings of the U.S. Global Change Research Program Climate Science Special Report", dalam Executive Summary. Washington, DC. 2017; Sahney, S., Benton, M.J. and Ferry, P.A. "Links between Global Taxonomic Diversity, Ecological Diversity and the Expansion of Vertebrates on Land", dalam Biology Letters. 6 (4) 2010: 544-547. Hawksworth, David L.; Bull, Alan T. Biodiversity and Conservation in Europe. (Springer, 2008). h. 3390; Ceballos, Gerardo, Ehrlich, Paul R., Barnosky, Anthony D., García, Andrés, Pringle, Robert M., Palmer, Todd M. "Accelerated Modern Human-Induced Species Losses: Entering the Sixth Mass Extinction", dalam Science Advances. 1 (5) 2015: Pimm, S. L., Jenkins, C. N., Abell, R.; Brooks, T. M., Gittleman, J. L., Joppa, L. N., Raven, P. H., Roberts, C. M., Sexton, J. O. (30 May 2014). "The Biodiversity of Species and their Rates of Extinction, Distribution, and Protection", dalam Science. 344 (6187): 124.

${ }^{11}$ Mangunjaya, op. cit., h. 90.
} 


\section{Al-Tarbawi Al-Haditsah: Jurnal Pendidikan Islam}

Vol. 3, No. 2, Desember 2018

Longgarnya pegangan manusia dalam ranah agama, mengakibatkan nilai-nilai agama yang ada pada diri seseorang melemah. Serta berdampak lepasnya pengendali yang ada pada diri manusia, sehingga manusia akan berbuat semaunya sendiri tanpa batas. Dapat dikatakan bahwa nilai-nilai agama yang mengantarkan manusia pada kearifan sikap dalam etika lingkungan hanya bersifat normatif belum sampai pada tataran praktik, oleh sebab itu perlu membangun kosmologi baru yang berbasis pada tradisi spiritual agama yang syarat akan makna dan kaya kearifan. Agama pun pada gilirannya bisa menjadi sumber inspirasi bagi pemerhati lingkungan untuk mengkonstruksi etika lingkungan sebagaimana program-program konservasi alam.

Menurut Manzoor, hak manusia untuk menguasai alam hanyalah dengan kebajikan, bukan untuk memberontak menentang Tuhan."12 Guna mengatasi problem lingkungan supaya tidak semakin akut, maka perlu langkah strategis dan berkesinambungan. Langkah yang dimaksud adalah melalui proses pendidikan.

Dalam hal ini Mujiono Abdilah dalam bukunya "Agama Ramah Lingkungan" mendefinisikan pendidikan sebagai wahana yang paling tepat untuk internalisasi dan transformasi pengetahuan dan nilai-nilai kearifan lingkungan yang terkandung dalam ajaran Islam. Pendidikan harus mampu merubah setiap jengkal dimensi kehidupan seseorang." 13

Perwujudan pendidikan agama Islam dalam usaha pelestarian lingkungan, yaitu dengan terselenggaranya lembaga pendidikan yang berwawasan lingkungan. Pada tahun 1996 disepakati kerjasama pertama antara Departemen Pendidikan Nasional dan Kementerian Negara Lingkungan Hidup, yang diperbaharui pada tahun 2005 dan tahun 2010. Sebagai tindaklanjut dari kesepakatan tahun 2005, pada tahun 2006

\footnotetext{
${ }^{12}$ S. Parvez Manzoor. "Lingkungan dan Nilai-nilai dalam Perspektif Islam", dalam Jurnal Ulumul Qur'an, Nomor 9 Volume 1 Tahun 1991, h. 65.

${ }^{13}$ Mujiono Abdilah. Agama Ramah Lingkungan. (Jakarta: Paramadina, 2001), h. 45; Prince Ghazi. The Holy Qur'an and the Environment. (The Hashemite Kingdom of Jordan: the Royal al al-Bayt Institute for Islamic Thought, 2010), h. 35.
} 
Al-Tarbawi Al-Haditsah: Jurnal Pendidikan Islam

Vol. 3, No. 2, Desember 2018

Kementerian Lingkungan Hidup mengembangkan program pendidikan lingkungan hidup pada jenjang pendidikan dasar dan menengah melalui program Adiwiyata. ${ }^{14}$ Program ini dilaksanakan di sepuluh sekolah di Pulau Jawa sebagai sekolah model dengan melibatkan Perguruan Tinggi dan LSM yang bergerak di bidang Pendidikan Lingkungan Hidup.

Program Adiwiyata dilaksanakan berdasarkan Peraturan Menteri Lingkungan Hidup Nomor 5 Tahun 2013 tentang Pedoman Pelaksanaan Program Adiwiyata. Peraturan Menteri Lingkungan Hidup Nomor 5 Tahun 2013 merupakan penyempurnaan dari Peraturan Menteri Negara Lingkungan Hidup Nomor 2 Tahun 2009. Pencapaian program Adiwiyata ini adalah 10\% dari total jumlah sekolah dasar dan menengah di Indonesia yang mencapai 191.362 dari SD sampai SMA/SMK atau kurang lebih 191.136 sekolah. ${ }^{15}$

SMK Negeri 1 Indramayu termasuk salah satu sekolah di Kabupaten Indramayu yang sudah masuk kategori sekolah Adiwiyata, dengan mendapat penghargaan dari Menteri Lingkungan Hidup.

Berkaitan dengan ini, menurut Siti Ana Maryana menyatakan bahwa:

"Pendidikan Agama Islam (PAI) yang dikolaborasikan dengan lingkungan hidup dalam kegiatan intrakurikuler, kokurikuler dan eksrakurikuler akan lebih mendapatkan hasil yang baik daripada hanya bertumpu pada satu kegiatan seperti ekstrakurikuler saja. Dalam kegiatan intrakurikuler dan kokurikuler dengan memuat materi tertentu dibuat satu rencana pembelajaran yang mengaitkan aspek pendidikan lingkungan hidup dalam berbagai strategi pembelajaran, sedangkan dalam kegiatan ekstrakurikuler pendidikan agama Islam dikolaborasikan dengangreen team."16

Dalam kegiatan pembelajaran masing-masing guru membuat satu rencana pembelajaran yang memuat tentang materi cinta lingkungan yang

\footnotetext{
${ }^{14}$ Program Adiwiyata adalah salah satu program Kementerian Lingkungan Hidup yang diluncurkan Tahun 2006 sebagai satu upaya untuk impelementasi pengembangan pendidikan lingkungan hidup di Indonesia. Lihat Pande Made Kutanegara. Membangun Masyarakat Indonesia Peduli Lingkungan, (Yogyakarta: Gadjah Mada University Press, 2014), h. 42

${ }^{15}$ Ibid, h. 43

${ }^{16}$ Hasil Wawancara dengan Ibu Siti Ana Maryana (Guru Pendidikan Agama Islam SMK Negeri 1 Indramayu), pada hari Jum'at Tanggal 27 Oktober 2017 Pukul 09.00 WIB. di Ruang Guru SMK Negeri 1 Indramayu Kabupaten Indramayu.
} 


\section{Al-Tarbawi Al-Haditsah: Jurnal Pendidikan Islam}

Vol. 3, No. 2, Desember 2018

diimplementasikan dalam kegiatan pembelajaran dengan tujuan wawasan lingkungan hidup yang diintegrasikan melalui kegiatan pembelajaran tersebut agar menjadikan peserta didik lebih mencintai lingkungannya. Begitu pula dengan mata pelajaran Pendidikan Agama Islam (PAI) yang didalamnya juga mengintegrasikan aspek-aspek lingkungan hidup yang diwujudkan dalam rencana pelaksanaan pembelajaran yang akan dilaksanakan.

Implementasi pembelajaran Pendidikan Agama Islam (PAI) berwawasan lingkungan hidup ini menjadi penting di SMK Negeri 1 Indramayu Kabupaten Indramayu karena sekolah ingin mewujudkan generasi-generasi cinta lingkungan, karena pada hakikatnya penciptaan manusia di bumi adalah sebagai khalifah yang hidup berdampingan dengan alam sekitar.

Keberhasilan pembelajaran Pendidikan Agama Islam (PAI) yang berwawasan lingkungan dipengaruhi beberapa faktor. Pendidikan Agama Islam (PAI) berwawasan lingkungan hidup ini terdapat dalam dua konsep. Konsep yang pertama yaitu terjabarkan melalui tiga pendekatan yang terdiri dari pendekatan manipulasi, pendekatan habituasi dan pendekatan keteladanan. Konsep kedua yaitu melalui struktur kurikulum yang mana Pendidikan Lingkungan Hidup diintegrasikan ke semua mata pelajaran termasuk mata pelajaran Pendidikan Agama Islam." 17

Implementasi pendidikan Agama Islam berwawasan lingkungan di SMK Negeri 1 Indramayu dikonsep dengan tujuan agar semua peserta didik dapat mencintai lingkungan dengan menumbuhkan perilaku yang peduli, menjaga, dan melestarikan lingkungan sebagai perwujudan dari penciptaan manusia sebagai khalifah dibumi.

Berangkat dari konsep tersebut, terdapat hubungan antara pendidikan Islam dan kesadaran dalam diri manusia kaitannya dengan lingkungan. Pendidikan Islam dan kesadaran dalam diri manusia memiliki hubungan yang

${ }^{17}$ Hasil Wawancara dengan Ibu Siti Ana Maryana (Guru Pendidikan Agama Islam SMK Negeri 1 Indramayu), pada hari Jum'at Tanggal 27Oktober2017 Pukul 09.00 WIB. di Ruang Guru SMK Negeri 1 Indramayu Kabupaten Indramayu. 


\section{Al-Tarbawi Al-Haditsah: Jurnal Pendidikan Islam}

Vol. 3, No. 2, Desember 2018

erat dalam mengatasi krisis lingkungan. Dalam hal ini, pendidikan berkaitan dengan fungsi intelektual yang didapatkan melalui proses pendidikan. Sedangkan agama Islam berkaitan dengan fungsi etis." 18

Berdasarkan konteks ini, agama Islam merupakan sumber inspirasi moralitas dan spiritualitas yang menjadi sebuah kebutuhan peradaban kontemporer.Keterlibatan agama Islam dalam konversi lingkungan dan penyelamatankerusakan bumi menjadi tak terelakkan. Salah satu tujuan pemahaman Islam multidimensional yang bisa mengintegrasikan secara proposional antara dimensi spiritual dan rasionalitas serta wawasan kosmetik dan humanistik secara bersamaan menjadi opsi yang menjanjikan untuk mengatasi krisis lingkungan dengan melalui pendidikan Islam berwawasan lingkungan." 19

Lingkungan sekolah yang rapi, rindang, bersih, sejuk, dan tenang menjadikan aktivitas belajar siswa berjalan dengan baik. Lingkungan sekolah dikelilingi dengan pepohonan yang rindang dan banyak area yang dikelilingi dengan tanaman seperti perpustakaan, masjid, ruang komputer serta tiap-tiap halaman kelas dengan disiapkan beberapa fasilitas untuk mendukung siswa dalam menjaga kelestarian lingkungan sekolah.

Di SMK Negeri 1 Indramayu kesadaran akan peduli lingkungan sudah tertanam pada warga sekolah yang berkeyakinan dengan lingkungan yang bersih akan mengantarkan pada prestasi belajar yang baik. Hal tersebut selaras dengan apa yang dikatakan oleh seketaris program sekolah berwawasan lingkungan:

"Lingkungan yang bersih, nyaman, dan rindang akan menciptakan proses pembelajaran yang kondusif. Perilaku peduli terhadap lingkungan yang diajarkan sekolah akan dibawa oleh siswa ke rumah dan masyarakat. Sehingga peduli terhadap lingkungan akan tertanam dalam diri warga sekolah dan terwujud dalam kehidupan sehari-hari. Implementasi pendidikan berwawasan lingkungan telah diintegrasikan dalam proses pembelajaran di semua mata pelajaran, termasuk mata

\footnotetext{
${ }^{18}$ Mulyono Abdilah. Fiqh Lingkungan: Panduan Spiritual Hidup Berwawasan Lingkungan. (Yogyakarta: Upp AMP YKPN, 2005), h. 47.

${ }^{19}$ Ibid, h. 48-49
} 


\section{Al-Tarbawi Al-Haditsah: Jurnal Pendidikan Islam}

Vol. 3, No. 2, Desember 2018

pelajaran Pendidikan Agama Islam. Pendidikan Agama Islam berwawasan lingkungan menjadi sebuah mata pelajaran yang bersifat interdisipliner." 20

Pengelolaan pembelajaran Pendidikan Agama Islam di SMK Negeri 1 Indramayu sebagai sebuah mata pelajaran yang meliputi aspek al-Qur'an, Hadits, Fiqih, Akidah, Akhlak, dan Tarikh terintegrasikan dengan pendidikan lingkungan hidup membawa pesan wawasan lingkungan pada peserta didik. Pendidikan Agama Islam juga diimplementasikan melalui aktivitas peserta didik di dalam sekolah sebagai wujud pengamalan terhadap ilmu yang diperolehnya. Dalam rangka menumbuhkan kesadaran berlingkungan sekolah memiliki beberapa kendala seperti masih adanya siswa yang kurang disiplin, kurang peduli dengan lingkungan sekitar baik di lingkungan sekolah secara menyeluruh ataupun di lingkungan kelas.

Selain itu juga ditemukan tujuan yang belum seimbang dan belum dipahami dengan baik oleh warga sekolah, belum adanya aturan dan sanksi pelaksanaan wawasan lingkungan hidup di sekolah, keterbatasan pedoman dan acuan mengenai wawasan lingkungan hidup, pengintegrasian pembelajaran wawasan lingkungan hidup belum berjalan dengan baik, kesadaran terhadap lingkungan masih belum maksimal, antara program kerja dan pelaksanaan masih kurang sinkron, kurang adanya kerjasama dan pengawasan dari Pihak terkait, belum ada tenaga khusus wawasan lingkungan hidup, wawasan lingkungan hidup belum dilaksanakan sepenuhnya.

Hal ini menjadi salah satu masalah bagi sekolah dalam mewujudkan visi sekolah dan tentunya guru pendidikan Agama Islam dalam menginternalisasikan nilai-nilai Pendidikan Agama Islam berwawasan lingkungan. Mengacu pada fenomena tersebut menjadi latar belakang penulis untuk mengadakan penelitian tentang "Implementasi Pendidikan Agama Islam (PAI) Berwawasan Lingkungan di SMK Negeri 1 Indramayu: Studi

${ }^{20}$ Hasil Wawancara dengan Bapak Rosyidin (Ketua Tim Adiwiyata SMK Negeri 1 Indramayu Kabupaten Indramayu), pada hari SelasaTanggal 31 Oktober 2017 Pukul 09.30 WIB.di Ruang Guru SMK Negeri 1 Indramayu Kabupaten Indramayu. 
Al-Tarbawi Al-Haditsah: Jurnal Pendidikan Islam

Vol. 3, No. 2, Desember 2018

Kasus tentang Kebijakan Pengelolaan Pembelajaran Pendidikan Agama Islam Berwawasan Lingkungan.”

\section{B. Metode Penelitian}

Jenis penelitian ini adalah penelitian kualitatif studi kasus dengan studi lapangan (field research) yang dimaksudkan untuk memahami fenomena tentang apa yang dialami oleh subjek penelitian: misalnya perilaku, persepsi, tindakan dan lain-lain, secara holistik dan dengan cara deskripsi dalam bentuk kata-kata dan bahasa, pada suatu konteks khusus yang alamiah dan dengan memanfaatkan berbagai metode ilmiah. ${ }^{21}$ Dalam studi kasus ini, penelitian bersifat spesifik, dengan tujuan untuk meneliti isu atau persoalan dengan menggunakan kasus tersebut untuk mengilustrasikan kompleksitas dari persoalan yang diteliti. ${ }^{22}$

Penelitian ini dilakukan selama kurang lebih 3 bulan mulai dari tanggal 06 Oktober 2017 sampai dengan 06 April 2018. Tempat yang akan dijadikan sebagai lokasi dalam penelitian ini adalah Sekolah Menengah Kejuruan (SMK) Negeri 1 Indramayu yang beralamat di Jalan Gatot Subroto Nomor 47, Karanganyar Kabupaten Indramayu. Informan kunci (key informant) dalam penelitian ini ialah guru mata pelajaran Pendidikan Agama Islam (PAI), peserta didik, kepala sekolah, dan ketua koordinator tim Sekolah Adiwiyata SMK Negeri 1 Indramayu Kabupaten Indramayu.

Untuk mengumpulkan data, peneliti menggunakan instrumen pengumpulan data yang digunakan yaitu observasi mendalam, wawancara mendalam, dan dokumentasi. Selanjutnya data yang terkumpul dianalisis melalui reduksi data, display data dan konklusi data.

\section{Temuan Penelitian}

1. Kebijakan Pendidikan Berwawasan Lingkungan di SMKN 1 Indramayu

${ }^{21}$ Lexy J. Moleong. Metodologi Penelitian Kualitatif. (Bandung: PT. Remaja Rosdakarya, 2004), h. 6 .

${ }^{22}$ John W. Creswell. Penelitian Kualitatif dan Design Research: Memilih di antara Lima Pendekatan. (Yogyakarta: Pustaka Pelajar, 2016), h. 171. 
Kebijakan pengelolaan pendidikan berwawasan lingkungan di SMK Negeri I Indramayu sudah ditunjukkan pada komponen fundamental input dan tata kelola. Fundamental input dalam hal ini meliputi visi, misi, tujuan, dan Motto SMK Negeri 1 Indramayu yang secara tegas telah menggiring terwujudnya proses pendidikan serta tata kelola ke wawasan lingkungan. Jika dianalisis terdapat pilar strategis tata kelola pendidikan yang termuat dalam visi misi SMK Negeri 1 Indramayu, yaitu "Kepedulian terhadap kesehatan dan pengelolaan serta pelestarian lingkungan hidup baik pada kegiatan tata kelola dan lulusan yang dihasilkannya".

Untuk menjamin terwujudnya empat pilar tersebut, secara manajerial SMK Negeri 1 Indramayu telah membentuk wakil kepala bidang kesiswaan, disiplin dan kebersihan lingkungan. Wakasek bidang ini diberi kewenangan untuk mengembangkan budaya konstruktif yang dapat membentuk siswa menjadi lulusan yang memiliki soft skill yang optimal yang akan membantu dalam dunia kerja, pengembangan karakter diri, dan lingkungan sosial.

Wawasan lingkungan yang terdapat pada Visi, Misi dan Tujuan menjadi dasar bagi pengembangan program baik terkait dengan pengembangan kelembagaan, sumberdaya manusia, serta kurikulum dan pembelajaran yang dituangkan dalam Renstra SMK Negeri 1 Indramayu.

Pada Renstra SMK Negeri 1 Indramayu disebutkan pengelolaan organisasi sekolah berpedoman pada sistem Manajemen Mutu SMK Negeri 1 Indramayu yang telah memenuhi sertifikasi ISO 9001:2008. Sedangkan pengelolaan pendidikannya mengacu pada Peraturan Pemerintah Nomor 19 Tahun 2005 tentang Standar Nasional Pendidikan.

Pengembangan kurikulum dilakukan secara berkesinambungan sesuai dengan tuntutan dan perkembangan dunia pendidikan dan dunia kerja dengan berpedoman kepada prinsip-prinsip pengembangan yang berlaku (termasuk prinsip pengembangan pembelajaran berbasis lingkungan).

Perencanaan pembelajaran dilakukan oleh tenaga pendidik baik secara individu maupun tim dengan melengkapi administrasi pembelajaran yang 


\section{Al-Tarbawi Al-Haditsah: Jurnal Pendidikan Islam}

Vol. 3, No. 2, Desember 2018

meliputi penyusunan silabus, program semester, Kriteria Ketuntasan Minimal (KKM), kisi-kisi soal serta Rencana Pelaksanaan Pembelajaran (RPP) untuk setiap tahun pelajaran dengan mengaplikasikan lingkungan sebagai ruh yang terintegrasi dalam perencanaan dan praktik pembelajaran.

Penyajian materi pembelajaran di SMK Negeri 1 Indramayu dilakukan di dalam kelas dan atau di laboratorium serta di tempat lainnya sesuai dengan materi pembelajaran dan menggunakan berbagai pendekatan serta metode yang dilengkapi dengan berbagai alat peraga pendidikan seperti media elektronik, peralatan praktikum atau dengan memanfaatkan jaringan internet. Bahan ajar yang diberikan sebagian besar telah disiapkan dalam bentuk modul pembelajaran yang berbasis lingkungan.

Peserta didik di SMK Negeri 1 Indramayu diberikan layanan konseling serta pembinaan untuk prestasi unggulan yang dimilikinya. Selain itu sekolah menyelenggarakan kegiatan ekstrakurikuler untuk menggali dan mengembangkan minat dan bakat siswa di bidang keorganisasian, olah raga, seni, kegamaan serta ilmu pengetahuan.

Untuk membangkitkan motivasi para peserta didik, sekolah menyelenggarakan pelatihan khusus yaitu Pelatihan Motivasi Berprestasi (Acievement Motivation Training). Di samping itu sekolah memberikan penghargaan bagi siswa yang memiliki prestasi baik di bidang akademik ataupun di bidang lainnya berupa beasiswa, hadiah, dan atau dinobatkan sebagai bintang pelajar termasuk siswa yang mempunyai inovasi di bidang lingkungan hidup.

Kebijakan yang diambil oleh SMK Negeri 1 Indramayu sesuai dengan Rencana Pembangunan Jangka Menengah Nasional (RPJMN) ke-3 (20152019) yaitu memantapkan pembangunan secara menyeluruh dengan menekankan pembangunan keunggulan kompetitif perekonomian yang berbasis Sumber Daya Alam (SDA) yang tersedia, SDM (Sumber Daya Manusia) yang berkualitas, dan kemampuan ilmu pengetahuan dan teknologi. 
2. Implementasi Pembelajaran Pendidikan Agama Islam (PAI) Berwawasan Lingkungan di SMKN 1 Indramayu

Pengelolaan tujuan pembelajaran PAI berwawasan lingkungan di SMK Negeri 1 Indramayu tertuang dalam perencanaan pembelajaran yang dilakukan oleh Guru PAI baik secara individu maupun tim dengan melengkapi administrasi pembelajaran yang meliputi penyusunan silabus, program semester, Kriteria Ketuntasan Minimal (KKM), kisi-kisi soal serta Rencana Pelaksanaan Pembelajaran (RPP) untuk setiap tahun pelajaran.

Pengklasifikasian tujuan pembelajaran PAI yang relevan dengan sekolah berbudaya lingkungan (Adiwiyata) dilakukan dengan cara mengintegrasikan materi dalam pendidikan lingkungan hidup ke dalam materi Pendidikan agama Islam yang relevan, seperti materi thaharah dan hadits tentang kebersihan. Kemudian, ikut berpartisipasi dalam pelaksanaan pendidikan karakter, terutama karakter peserta didik yang peduli dan cinta dengan lingkungan.

Secara lebih rinci, aspek-aspek yang menjadi pedoman dalam implementasi pembelajaran Pendidikan Agama Islam (PAI) berwawasan lingkungan di SMK Negeri 1 Indramayu agar sesuai dengan tujuan yang diharapkan, berdasarkan analisis peneliti terdapat beberapa aspek mendasar dalam pelaksanaannya, aspek tersebut antara lain:

a. Silabus

Silabus yang dijadikan acuan guru PAI dalam pengimplemantasian pembelajaran PAI berwawasan lingkungan di SMK Negeri 1 Indramayu yang kemudian di-breakdown lebih detail dalam perencanaan pembelajaran selalu menjadi acuan utama agar proses pembelajaran tetap terarah pada tujuan pembelajaran yang sesuai dengan SKL yang ditetapkan oleh pemerintah walaupun pengimplementasiannya tetap mengedepankan corak wawasan lingkungan pada setiap pelaksanaan pembelajarannya. 
Dalam silabus pembelajaran PAI, beberapa poin yang mengandung muatan tujuan PAI berwawasan lingkungan tertuang dalam pengembangan materi pembelajaran dan kegiatan pembelajaran yang harus mengintegrasikan muatan lingkungan hidup di dalamnya. Dari beberapa materi yang tercantum di atas guru PAI mengintegrasikan materi tersebut ke dalam pendidikan lingkungan, sehingga materi PAI selaras dengan kebijakan sekolah tentang program Adiwiyata.

b. Rencana Pelaksanaan Pembelajaran (RPP)

Dalam penyusunan Rencana Pelaksanaan Pembelajaran (RPP) mata pelajaran Pendidikan Agama Islam (PAI) di SMK Negeri 1 Indramayu, penyampaian materi lingkungan hidup pada mata pelajaran PAI kepada peserta didik sejatinya dapat dilakukan melalui penyusunan RPP baik secara terintegrasi atau monolitik. Pengembangan materi, model pembelajaran, dan metode belajar yang bervariasi dilakukan untuk memberikan pamahaman kepada peserta didik tentang lingkungan hidup yang dikaitkan dengan persoalan lingkungan sehari-hari. Tema lingkungan hidup diharapkan menjadi kerangka utama dalam pengembangan dan penyusunan rencana pembelajaran PAI berbasis lingkungan hidup. Secara lebih spesifik, pengelolaan dan pengembangan Rencana Pelaksanaan Pembelajaran (RPP) berwawasan lingkungan pada mata pelajaran PAI terletak pada aspek tujuan dan materi.

Dilihat dari segi materi pelajaran atau kurikulum, Pendidikan Agama Islam (PAI) terhadap lingkungan banyak sekali kaitannya. Diantaranya adalah memberi arahan dalam penggunaan sumber daya alam serta pelestariannya secara cermat dan bijaksana. ${ }^{23}$,

c. Integrasi Pembelajaran PAI berwawasan lingkungan

Dari hasil observasi yang dilakukan, guru PAI di SMK Negeri 1 Indramayu dalam proses pembelajaran menggunakan buku guru dan buku siswa sebagai bahan atau sumber materi ajar, namun buku guru dan

${ }^{23}$ Hery Noer Aly.1999. Ilmu Pendidikan Islam. (Jakarta: Logos, 1999), h. 13. 
buku siswa yang disediakan Pemerintah belum meng-cover secara lebih merinci muatan-muatan wawasan lingkungan. Untuk kebutuhan itu, MGMP PAI SMK Negeri 1 Indramayu menyusun modul tersendiri guna mengembangkan materi pembelajaran dan indikator pembelajaran PAI yang berkaitan dengan masalah-masalah lingkungan sekitar (isu local) dan masalah-masalah lingkungan secara luas (isu global). Isu lokal mencakup isu lingkungan hidup yang ada di wilayah sekitar sekolah, yang merupakan potensi ketersedian sumber daya alam dan kearifan lingkungan, terkait perlindungan dan pengelolaan lingkungan hidup yang dapat berdampak pada banjir, longsor, kekeringan, pencemaran sampah, pencemaran air/udara/tanah, penggundulan hutan, kabut asap dan kebakaran hutan, dan lain-lain, sedangkan isu global mencakup isu lingkungan hidup misalnya terkait: energi, ozon, perubahan iklim, keanekaragaman hayati, bahan berbahaya dan beracun, tumpahan minyak di laut, rekayasa genetik dan lain lain.

Buku guru dan siswa yang diterbitkan oleh Kementerian Pendidikan dan Kebudayaan yaitu "Pendidikan Agama Islam dan Budi Pekerti" selama ini dirasakan belum cukup untuk menjadi acuan dasar dalam pengimplementasian pembelajaran PAI berwawasan lingkungan di SMK Negeri 1 Indramayu. Maka MGMP PAI SMK Negeri 1 Indramayu menyusun modul Pembelajaran PAI yang terintegrasikan dengan Lingkungan Hidup. Selain buku Guru dan Siswa yang diterbitkan oleh pemerintah dalam hal ini Kementreian Pendidikan dan Kebudayaan pada pelaksanaan pembelajaran juga menggunakan referensi-referensi lain yang terkait dengan setiap materi yang disampaikan baik yang di sediakan oleh sekolah dalam hal ini perpustakan maupun siswa mencari dan memiliki sendiri, buku yang sering digunakan adalah Buku Pendidikan Agama Islam dan Budi Pekerti karya H.M Nasikin terbitan Erlangga. 
Dalam buku itu meliputi Kurikulum sebagai acuan guru dalam memberikan materi, setiap masuk materi di awali dengan peta konsep, yang menggambarkan point-point yang menjadi titik tekan pembahasan. Kemudian disajikan gambar yang berkaitan dengan materi untuk menggugah siswa memunculkan pengetahuan dasarnya.

Pada pembahasan berikutnya adalah disajikan materi pembelajaran sampai kepada rangkuman, dan disajikan pula tugas mandiri dan terstruktur untuk dikembangkan oleh guru. Sampai di akhir setiap bab diakhiri dengan evaluasi baik aspek pengetahuan maupun sikap spiritual dan sosial.

Dari temuan-temuan peneliti di lapangan melalui proses wawancara, observasi dan studi dokumentasi, secara lebih rinci penulis akan melakukan analisis pembahasan dari temuan penelitian dengan konstruksi teori yang ada sebagai berikut:

Banyaknya ayat-ayat al-Qur'an menyebutkan hubungan antara alam danmanusia diperoleh ajaran bahwa fungsi manusia terhadap alam lingkungannya, dan dalam waktu sama juga memelihara kelestarian dan mengembangkan potensinya, agar dapat melayani kebutuhan hidup manusia sepanjang umur manusia.

Tetapi perlu diperhatikan bahwa dalam memenuhi fungsi terhadap alam itu, hendaknya selalu diusahakan agar keselamatan manusia tidak terganggu. Tidak memanfaatkan potensi alam secara berlebih-lebihan, agar generasi mendatang masih berkesempatan menikmatinya, karena potensi terbatas. Berlebih-lebihan dalam memanfaatkan potensi alam berakibat kerusakan dalam hidup manusia sendiri. Menebangi gundul hutan-hutan misalnya akan berakibat banjir dan longsor, pada akhirnya manusia sendiri yang akan terkena akibatnya. Dari sini dapat diketahui betapa pentingnya peringatan yang diamanatkan Allah dalam QS. ArRuum [30] Ayat: 41 
Dari temuan-temuan peneliti di lapangan melalui proses wawancara mendalam, observasi mendalam dan studi dokumentasi maka terlihat bahwa implementasi pengembangan materi pembelajaran PAI berwawasan lingkungan ini dilaksanakan dengan guru PAI di SMK Negeri 1 Indramayu menjadikan buku pegangan guru dari pemerintah sebagai acuan pokok ditambah dengan sumber lain yang relevan. Disamping itu guru PAI di SMK Negeri 1 Indramayu dituntut untuk menyusun materi pembelajaran yang diintegrasikan langsung kepada masalah lingkungan dengan tanpa merubah materi pokok yang ada dalam kurikulum PAI. Hal ini dilaksanakan dengan cara MGMP mata Pelajaran PAI bersama-sama menyusun materi pembelajaran yang terintegrasi dengan masalah lingkungan.

Guru dan cara mengajar yang relevan dengan kebijakan sekolah Adiwiyata di SMK Negeri 1 Indramayu diaplikasikan melalui pendekatan, strategi, metode, dan teknik pembelajaran PAI. Dilakukan melalui: formulasi kegiatan atau proses pembelajaran PAI melalui penerapan pendekatan, strategi, metode, dan teknik pembelajaran yang melibatkan peserta didik secara aktif dalam pembelajaran. Metode pembelajaran yang dimaksud adalah cara belajar aktif yang berfokus pada peserta didik, misalnya dengan demonstrasi, diskusi, simulasi, bermain peran, laboratorium, pengalaman lapangan, dialog, simposium, dan lain-lain. Kemudian merancang pembelajaran di dalam maupun di luar kelas dengan memanfaatkan lingkungan sebagai sumber/media pembelajaran.

Pengelolaan pembelajaran Pendidikan Agama Islam (PAI) berwawasan lingkungan hidup di SMK Negeri 1 Indramayu Kabupaten Indramayu mendorong sekolah yang ada menjadi sekolah yang ramah lingkungan, nyaman untuk ditempati siswa yang akan berakibat pada meningkatnya rasa betah belajar di sekolah sehingga berimplikasi positif pada konsentrasi dan prestasi peserta didik yang meningkat. Dan 


\section{Al-Tarbawi Al-Haditsah: Jurnal Pendidikan Islam}

Vol. 3, No. 2, Desember 2018

diharapkan konsep pembelajaran seperti ini terus kontinu diberlakukan untuk semua sekolah dan terintegrasi ke semua mata pelajaran yang diajarkan bukan hanya pada mata pelajaran PAI dan juga tidak hanya ditunjuk beberapa sekolah. Program adiwiyata juga sebagai upaya melaksanakan satu perintah dan tuntunan agama kita (Islam) sebagai salah satu upaya untuk menjaga lingkungan, karena kalau kita tidak menjaganya maka akibatnya akan dirasakan oleh kita sendiri." 24

Pengelolaan pembelajaran PAI dikolaborasikan dengan lingkungan hidup dalam kegiatan intrakurikuler, kokurikuler dan eksrakurikuler, hal ini dilakukan guna mendapatkan hasil yang lebih baik daripada hanya bertumpu pada satu kegiatan seperti ekstrakurikuler saja. Dalam kegiatan intrakurikuler dan kokurikuler dengan memuat materi tertentu dibuat satu rencana pembelajaran yang mengaitkan aspek pendidikan lingkungan hidup dalam berbagai strategi pembelajaran, sedangkan dalam kegiatan ekstrakurikuler PAI dikolaborasikan dengan tim green team." 25

Pembelajaran berwawasan lingkungan pada sekolah Adiwiyata di mana setiap mata pelajarannya berbasis lingkungan termasuk pada mata pelajaran PAI di dalamnya. Aktivitas peserta didik diarahkan untuk menjaga lingkungannya dimulai dari ruangan kelas, area taman depan kelas dan lingkungan sekitar. Terbentuknya suatu organisasi yang tanggap terhadap lingkungan juga menjadi program dalam melestarikan lingkungan yang meliputi beberapa kegiatan seperti pengolahan sampah, produksi pupuk, budidaya tanaman dan segala hal tersebut dilakukan

\footnotetext{
${ }^{24}$ Hasil Wawancara dengan Bapak Jenjen Jaeni Dahlan (Kepala Sekolah SMK Negeri 1 Indramayu Kabupaten Indramayu) pada Hari Selasa 14 Nopember 2017 Pukul 09.15 WIB. di Ruang Kepala SMK Negeri 1 Indramayu.

${ }^{25}$ Hasil Wawancara dengan Bapak Rosyidin (Ketua Tim Adiwiyata SMK Negeri 1 Indramayu Kabupaten Indramayu) pada Hari Jum'at 17 Nopember 2017 Pukul 11.20 WIB. di Ruang Guru SMK Negeri 1 Indramayu.
} 
untuk mengarahkan peserta didik dalam mengamalkan nilai-nilai Islam dalam rangka menjaga lingkungan hidup." 26

Mata pelajaran Pendidikan Agama Islam (Islam) yang diajarkan Guru PAI saya tidak melulu tentang hafalan dan praktik-praktik. Di SMK Negeri 1 Indramayu mata pelajaran PAI yang saya rasakan sebagai siswa diajarkan dengan menarik selain menambah wawasan bagi saya tentang keagamaan, mata pelajaran PAI juga mengajarkan agar kita hidup berdampingan dengan lingkungan dan tidak mencemari apalagi merusaknya."27

Sedangkan metode yang diterapkan dalam Pendidikan Agama Islam (PAI) untuk mewujudkan kelestarian lingkungan di SMK Negeri 1 Indramayu banyak sekali, hal ini diterapkan oleh para guru mata pelajaran Pendidikan Agama Islam dalam rangka pengintegrasian mata pelajaran kepada pendidikan lingkungan hidup. Adapun metode-metode yang digunakan, yaitu:

1) Metode Keteladanan

Secara teknis metode ini implementasinya pada mata pelajaran Pendidikan Agama Islam di SMK Negeri 1 Indramayu diterapkan oleh guru dalam beberapa hal:

a) Ikut berpartisipasi pada kegiatan jum'at bersih, dimana kegiatan ini merupakan kegiatan rutin yang dilaksanakan dan harus diikuti oleh seluruh warga SMK Negeri 1 Indramayu baik siswa, guru ataupun tenaga Administrasi sekolah.

b) Bersama-sama dengan siswa mengembangkan apotik hidup dan taman sekolah. Di SMK Negeri 1 Indramayu ada beberapa bagian lahan yang dijadikan sebagai kawasan Toga dan Apotik hidup.

\footnotetext{
${ }^{26}$ Hasil Wawancara dengan Ibu Siti Ana Maryana (Guru PAI SMK Negeri 1 Indramayu Kabupaten Indramayu) pada Hari Jum'at 17 Nopember 2017 Pukul 13.00 WIB. di Ruang Rohis SMK Negeri 1 Indramayu.

${ }^{27}$ Hasil Wawancara dengan Firda Komalasari (Siswi Kelas XI SMK Negeri 1 Indramayu Kabupaten Indramayu) pada Hari Selasa 21 Nopember 2017 Pukul 10.00 WIB. di Ruang Keagamaan SMK Negeri 1 Indramayu.
} 
c) Berpartisipasi aktif dalam kegiatan aksi lingkungan hidup yang dilakukan oleh pihak luar sekolah, kegiatan ini diantaranya adalah kegiatan kerjasama dengan Dinas Lingkungan Hidup, dengan UP VI Pertamina dan juga dengan organisasi kemasyarakatan.

d) Memberi contoh dalam peningkatan upaya penghematan energi, air, dengan menutup kran air ketika selesai mengunakannya dan termasuk menggunakan air secukupnya ketika berwudu atau aktivitas lainnya yang membutuhkan air.

e) Mempelopori reboisasi /penghijauan di lingkungan sekolah dan wilayah setempat. SMK Negeri 1 Indramayu merupakan salah satu SMK Negeri di Kabupaten Indramayu yang dianggap memiliki lahan hijau yang representatif dan bagus.

2) Metode Pembiasaan

Secara teknis metode ini implementasinya pada mata pelajaran Pendidikan Agama Islam di SMK Negeri 1 Indramayu diterapkan oleh guru dalam beberapa hal: ${ }^{28}$

a) Adanya piket kelas yang rutin harus dilaksanakan oleh siswa SMK Negeri 1 Indramayu setiap akan pulang dan akan memulai belajar

b) Adanya pemilahan tempat sampah antara sampah organik, dan non organik, sehingga siswa terbiasa membuang sampah pada tempatnya karena sudah faham perbedaan antara kedua macam sampah berdasarkan tempatnya.

c) Adanya lomba kebersihan yang rutin dilaksanakan oleh sekolah dan setiap satu bulan sekali diumumkan hasilnya.

d) Adanya gerakan amal bakti sosial dan lingkungan pada masyarakat sekitar sekolah.

e) Adanya kegiatan ekstrakurikuler di sekolah yang mendukung pengembangan Pendidikan Lingkungan Hidup.

${ }^{28}$ Hasil observasi dan wawancara dengan H. Mukim (Guru PAI SMK Negeri 1 Indramayu Kabupaten Indramayu) pada Hari Senin 4 Desember 2017 Pukul 11.00 WIB. di Ruang Rohis SMK Negeri 1 Indramayu. 
f) Melaksanakan pemeliharaan dan pengecekan rutin biopori-biopori yang sudah dibuat oleh sekolah bersama-sama dengan siswa.

g) Siswa ikut aktif dalam pengembangan sistem pengelolaan sampah.

3) Memberi Nasihat

Secara teknis metode ini implementasinya pada mata pelajaran Pendidikan Agama Islam di SMK Negeri 1 Indramayu diterapkan oleh guru dalam beberapa hal: ${ }^{29}$

1) Selalu menyisipkan pesan moral tentang pemeliharaan lingkungan dan lingkungan bersih pada setiap upacara / apel.

2) Penyediaan layanan konsultasi bagi peserta didik di ruang keagamaan.

3) Memberikan sanksi atas pelanggaran yang dilakukan siswa secara bertahap dari mulai lisan, tulisan dan panggilan orangtua.

4) Adanya peringatan Hari Besar Islam dengan mendatangkan mubaligh dari luar sekolah sebagai upaya mengingatkan dan menasehati siswa, agar siswa tidak merasa jenuh dengan nasehat yang diberikan langsung dan rutin oleh guru.

5) Guru mengawali dan mengakhiri pelajaran dengan memberikan pesan tentang $\mathrm{K} 7$ kaitannya dengan ajaran agama.

4) Metode Diskusi

Metode ini implementasinya pada mata pelajaran Pendidikan Agama Islam di SMK Negeri 1 Indramayu diterapkan oleh guru dalam beberapa hal: ${ }^{30}$

a) Melakukan pembelajaran kolaboratif penelitian mini yang kemudian dibentuk kelompok-kelompok diskusi untuk memaparkan hasil mini research tersebut. Seperti hasil observasi

\footnotetext{
${ }^{29}$ Hasil observasi dan wawancara dengan Ibu Siti Ana Maryana (Guru PAI SMK Negeri 1 Indramayu Kabupaten Indramayu) pada Hari Senin 4 Desember 2017 Pukul 13.00 WIB. di Ruang Rohis SMK Negeri 1 Indramayu.

${ }^{30}$ Hasil observasi dan wawancara dengan H. Mukim (Guru PAI SMK Negeri 1 Indramayu Kabupaten Indramayu) pada Hari Senin 4 Desember 2017 Pukul 11.00 WIB. di Ruang Rohis SMK Negeri 1 Indramayu.
} 
peneliti siswa melakukan penelitian mini dengan mendapatkan tugas dari guru PAI untuk berkelompok kemudian ditugaskan mencari dan melihat langsung sebab-sebab kerusakan alam yang terjadi di lingkungannnya dengan mengikuti kegiatan yang bersifat partisipatif. Kemudian hasil dari penelitian yang dilakukan oleh siswa didiskusikan dalam kelompok-kelompok kecil, observasi yang dilakukan oleh peneliti yaitu pada tahapan diskusinya dimana siswa pada periode sebelumnya sudah melakukan penelitian mini. Tujuan dari mini reseach ini adalah siswa mendapatkan pengetahuan tidak hanya sekedar dalam bentuk teori secara verbal tapi juga melihat secara langsung. Materi yang diterapkan dengan metode ini adalah materi tentang kerusakan alam.

b) Pada kegiatan Rohis adanya kegiatan mentoring, dimana dalam kegiatan mentoring siswa juga senantiasa diajak untuk berdiskusi beberapa hal termasuk di dalamnya hal-hal yang berkaitan dengan masalah kelestarian alam.

5) Metode Kisah

Dari hasil observasi yang dilakukan oleh peneliti Pengaplikasian metode ini pada mata pelajaran Pendidikan Agama Islam di SMK Negeri 1 Indramayu diterapkan oleh guru PAI dalam beberapa hal: ${ }^{31}$

a) Dalam menyampaikan materi tentang tanggung jawab guru menyampaikan kisah kepada siswa terkait dengan masalah lingkungan, seperti ketika pengiriman pasukan ke Negeri Syam yang dipimpin oleh Yazid Bin Abi Sofyan, Abu Bakar menginstruksikan kepada pasukan, ada sepuluh hal yang dipesankannya,diantaranya: "Jangan menebang pohon yang berbuah dan jangan membakar pohon kurma."

\footnotetext{
${ }^{31}$ Hasil Wawancara dengan Ibu H. Suwaebah (Guru PAI SMK Negeri 1 Indramayu Kabupaten Indramayu) pada Hari Senin 4 Desember 2017 Pukul 14.00 WIB. di Ruang Rohis SMK Negeri 1 Indramayu.
} 
b) Dalam menyampaikan materi sebab-sebab kerusakan di muka bumi disampaikan kisah Tsunami di Aceh, bagaimana fenomena alam itu sangat dahsyat dan memakan korban yang sangat banyak, gempa di Yogyakarta yang meruntuhkan banyak sekali rumah penduduk dan manusia yang tertimpa reruntuhan, serta bencana banjir di Jakarta. Metode kisah atau cerita seperti disebutkan, dapat disampaikan kepada siswa dengan tujuan untuk menyampaikan betapa bencana-bencana telah merusak alam kita, ulah manusia sendirilah yang sebenarnya menimbulkan kerusakan pada alam dan bencana. Kisah-kisah tersebut akan menyentuh jiwa jika disadari oleh ketulusan hati yang mendalam, sehingga siswa dapat mencari solusi atas masalah yang terjadi, dan lebih mencintai alam tanpa harus menimbulkan kerusakan.

c) Menyampaikan kisah, para sahabat dan orang-orang masa kini yang inspiratif yang berjasa pada bidang-bidang tertentu, termasuk lingkungan hidup.

6) Metode Karyawisata

Secara teknis metode ini implementasinya pada mata pelajaran Pendidikan Agama Islam di SMK Negeri 1 Indramayu diterapkan oleh guru dalam beberapa hal, salah satu di antaranya yakni melakukan kunjungan wisata terhadap tempat-tempat yang secara historis memiliki nilai kereligiusan tertentu, atau juga pada tempat-tempat dan lokasi yang memiliki nilai edukasi berwawasan lingkungan bagi peserta didik." $" 32$

Kegiatan dengan metode karyawisata ini yang dilakukan oleh siswa-siswi SMK Negeri 1 Indramayu yaitu dengan berkunjung ke kawasan Pantai Karangsong dan hutan Mangrove, disana siswi selain melihat fenomena alam siswa-siswi juga mengadakan kegiatan lainnya yaitu adanya kegiatan menanam mangrove, membersihkan

\footnotetext{
${ }^{32}$ Hasil observasi pada Hari Senin 4 Desember 2017.
} 


\section{Al-Tarbawi Al-Haditsah: Jurnal Pendidikan Islam}

Vol. 3, No. 2, Desember 2018

sampah di sekitar pantai dan juga kegiatan penyuluhan kepada masyarakat sekitar pesisir pantai.

7) Metode Persuasi

Secara teknis metode ini implementasinya pada mata pelajaran Pendidikan Agama Islam di SMK Negeri 1 Indramayu diterapkan oleh guru dalam beberapa hal, salah satu di antaranya yakni mengajak dan menyakinkan peserta didik dengan menyajikan atau menayangkan fenomena-fenomena tertentu dengan tujuan memberi penguatan akidah peserta didik baik itu melalui tayangan audio-visual atau juga dengan teknik-teknik lainnya.

Dalam hal ini setiap pembelajaran sekolah sudah menyiapkan perangkat Audio Visual untuk dipergunakan guru dalam pembelajarannya. Di SMK Negeri 1 Indramayu guru PAI menyampaikan materi dilengkapi dengan perangkat pembelajaran yang didalamnya sudah terdapat audio visual yang akan diberikan kepada siswa sesuai dengan temanya masing-masing. ${ }^{33}$

Murid dan cara belajar yang relevan dengan kebijakan sekolah Adiwiyata di SMK Negeri 1 Indramayu diaplikasikan melalui beberapa cara, antara lain: pembelajaran disetting untuk menghasilkan karya yang berkaitan dengan pelestarian fungsi lingkungan hidup, pengendalian pencemaran dan kerusakan lingkungan hidup, menerapkan pengetahuan lingkungan hidup yang diperoleh untuk memecahkan masalah lingkungan hidup dalam kehidupan sehari-hari dan mengkomunikasikan hasil pembelajaran lingkungan hidup dengan berbagai cara dan media.

Proses pembelajaran PAI di SMK Negeri 1 Indramayu murid tidak hanya sekedar objek tapi disini murid juga diberikan keleluasaan untuk punya peran dalam pembelajarannya. Murid di SMK Negeri 1

\footnotetext{
${ }^{33}$ Hasil Wawancara dengan Ibu Siti Ana Maryana (Guru PAI SMK Negeri 1 Indramayu Kabupaten Indramayu) pada Hari Senin 4 Desember 2017 Pukul 13.00 WIB. di Ruang Rohis SMK Negeri 1 Indramayu.
} 
Indramayu belajar secara aktif dalam berbagai proses pembelajaran. Hal yang terlihat saat observasi murid-murid SMK Negeri 1 Indramayu di ajak guru PAI untuk memeriksa biopori-biopori yang ada di lingkungan sekolah apakah masih berfungsi atau belum, di sisi lain juga ada siswa yang melakukan pemilahan sampah-sampah yang sudah terkumpul, yang kemudian sampah-sampah yang bisa di daur ulang di berikan ke bank sampah yang dikelola oleh tim Adiwiyata.

d. Kegiatan Ekstrakurikuler

Siswa diberikan kesempatan untuk memilih kegiatan ekstra kurikuler sesuai dengan minat dan bakat siswa.Dalam kegiatan ekstra kurikuler ini juga seluruh Pembina mengarahkan kegiatannya terintegrasi kepada wawasan lingkungan. Kegiatan ekstra kurikuler yang ada di SMK Negeri 1 Indramayu adalah: Pramuka, Paskibra, PMR, Bela diri, Kesenian, Olahraga, Rohis, KIR.

Pengintegrasian kegiatan ekstrakurikuler dengan wawasan lingkungan dilaksanakan adanya kegiatan rutin aksi sosial untuk penghijauan lingkungan dari setiap bidang ekstrakurikuler. Adanya lomba daur ulang dari barang bekas di setiap bidang ekstra kurikuler. Setiap pelantikan anggota dari masing-masing ekstra kurikuler selalu dilaksanakan di luar sekolah tapi ditempat yang berbasis lingkungan. Dalam kegiatan intrakurikuler OSIS sebagai organisasi intra sekolah melaksanakan beberapa program terkait dengan masalah lingkungan yaitu: (a). Program Majlis Ta'lim setiap Jum'at Pagi yang diawali dhuha bersama, (b). Jum'at bersih yang dilaksanakan jum'at siang setelah KBM, yang sebelumnya dilaksanakan setiap sabtu pagi, (c). Lomba kebersihan dan kerapihan antar kelas yang diumumkan pada pelaksanaan Hari jadi sekolah, (d). Penyuluhan K7 oleh sekolah dan juga instansi pemerintah yang terkait atau pun pihak swasta, (e). Penghijauan dan penanaman toga di setiap bagian-bagian lingkungan sekolah yang di koordinir oleh jurusan masing-masing. 


\section{Al-Tarbawi Al-Haditsah: Jurnal Pendidikan Islam}

Vol. 3, No. 2, Desember 2018

e. Evaluasi

Beberapa teknik dalam pengelolaan evaluasi dan penilaian pembelajaran PAI berwawasan lingkungan di SMK Negeri 1 Indramayu dilakukan menggunakan instrumen authentic assessment dengan cara mengembangkan indikator dan instrumen penilaian pembelajaran PAI yang terintegrasi pada lingkungan hidup, artinya bahwa pembelajaran PAI dan lingkungan hidup baik secara integrasi maupun monolitik harus dilengkapi dengan indikator penilaian tingkat keberhasilan.

Pembelajaran Pendidikan Agama Islam (PAI) digunakan sebagai pemecahan masalah yang berkaitan dengan alam, karena di dalamnya ada aturan-aturan alam (hukum alam) yang dipakai sebagai etika dalam menciptakan kelestarian lingkungan.

Berdasarkan hasil observasi dan wawancara di lapangan pengelolaan evaluasi dan penilaian pembelajaran PAI berwawasan lingkungan di SMK Negeri 1 Indramayu memiliki nilai plus-minus, sehingga diperoleh temuan sebagai berikut:

1) Penilaian dan evaluasi dilakukan secara berkala oleh setiap guru, baik penilaian setiap KD yang disampaikan, Evaluasi setiap tengah semester (PTS), evaluasi akhir semester (PAS) ataupun evaluasi setiap akhir TahunPelajaran (PAT).

2) Teknik penilaian yang dilaksanakan yaitu tes lisan, tulisan dan praktek juga penilaian sikap.

3. Faktor Pendukung dan Penghambat Implementasi Pembelajaran PAI Berwawasan Lingkungan di SMKN 1 Indramayu

a. Faktor pendukung

Dalam pelaksanaan pengelolaan pembelajaran berwawasan lingkungan hidup di SMK Negeri 1 Indramayu Kabupaten Indramayu bukan hanya saja pada mata pelajaran PAI, yang menjadi faktor pendukung dalam proses pelaksanaannya antara lain: SMK Negeri 1 Indramayu sudah menjadi sekolah dengan kategori sekolah Adiwiyata 


\section{Al-Tarbawi Al-Haditsah: Jurnal Pendidikan Islam}

Vol. 3, No. 2, Desember 2018

sehingga punya dasar untuk mengintegrasikan wawasan lingkungan ini ke semua mata pelajaran termasuk mata pelajaran PAI, semua unsur baik tenaga pendidik maupun tenaga kependidikan mengapresiasi positif sehingga mereka meaksanakan kebijakan ini dalam kerjanya, adanya pendidikan dan pelatihan untuk guru berkaitan dengan masalah lingkungan dan guru yang mengikuti ini desiminasi kepada guru lainnya, dukungan dari Pemerintah dan beberapa perusahaan dalam menyiapkan sarana pembelajaran berwawasan lingkungan (bantuan berupa pelatihan daur ulang sampah, pembuatan biopori, tempat sampah dan bantuan tanaman). ${ }^{34}$ Pembelajaran ini selanjuntnya mendapat dukungan dari seluruh stake holder sekolah dan dukungan dari Pemerintah Daerah baik berupa pembinaan dan bantuan sarana dan prasarana kebersihan dan penghijauan. ${ }^{35}$

Faktor pendukung yang lain adalah adanya kebijakan sekolah tentang pengintegrasian pendidikan lingkungan kepada semua mata pelajaran, kebijakan sekolah sesuai dengan tuntunan agama yang harus diberikan kepada siswa pada mata pelajaran PAI, banyaknya metode pembelajaran yang bisa diterapkan dalam KBM seperti pendekatan scientific approach juga dipakai dalam pembelajaran di Kurikulum 2013 yang meliputi kegiatan mengamati, menanya, mencoba, mengolah, menyajikan, menyimpulkan dan menciptakan, ini menjadi gerbang emas untuk mengimplementasikan pembelajaran PAI berwawasan lingkungan dengan leluasa. Sehingga dengan menggunakan pendekatan ini mampu menumbuhkan kreativitas, rasa ingin tahu, berpikir kritis dan kemampuan belajar peserta didik dapat menjadi kebiasaan-kebiasaan yang dijadikan kebiasaan sepanjang hayat, dan siswa merasa senang

\footnotetext{
${ }^{34}$ Hasil observasi dan wawancara dengan Bapak Jenjen Jaeni Dahlan (Kepala Sekolah SMK Negeri 1 Indramayu Kabupaten Indramayu) pada Hari Kamis 16 Nopember 2017 Pukul 09.15 WIB. di Ruang Kepala SMK Negeri 1 Indramayu.

${ }^{35}$ Hasil Wawancara dengan Bapak Rosyidin (Ketua Tim Adiwiyata SMK Negeri 1 Indramayu Kabupaten Indramayu) pada Hari Jum'at 17 Nopember 2017 Pukul 11.20 WIB. di Ruang Guru SMK Negeri 1 Indramayu.
} 


\section{Al-Tarbawi Al-Haditsah: Jurnal Pendidikan Islam}

Vol. 3, No. 2, Desember 2018

dengan adanya praktik langsung dalam pembelajaran PAI berwawasan lingkungan. ${ }^{36}$

b. Faktor penghambat

Sedangkan yang menjadi faktor penghambatnya antara lain adalah adanya perubahan kurikulum dari Pemerintah Pusat dari KTSP ke Kurikulum 2013 kemudian Revisi Kurikulum 2013, perubahan hari efektif belajar dari 6 hari KBM menjadi 5 hari KBM sehingga yang tadinya ada beberapa waktu yang bisa dipakai untuk gerakan K7 bersama, menjadi berkurang waktunya karena padatnya jadwal yang harus diselesaikan sampai sore hari, dan terbatasnya anggaran sekolah untuk penambahan dan pemeliharaan fasilitas-fasilitas sekolah yang mendukung tetap terciptanya sekolah yang nyaman, rindang karena bantuan dari Pemerintah dan perusahaan hanya terbatas pada saat akan diadakannya penilaian. ${ }^{37}$

Faktor penghambat yang lain ialah pemeliharaan fasilitias pendukung sekolah Adiwiyata yang tidak teranggarkan dengan maksimal serta perlunya tindakan ekstra terhadap peserta didik baru terkait denganrole of play dari proses pembelajaran berbasis lingkungan yang belum mereka ketahui sepenuhnya. ${ }^{38}$ Disamping itu, adanya perubahan kurikulum yang diberlakukan di sekolah, tidak adanya materi khusus tentang menjaga kelestarian lingkungan di Kurikuum 2013 Revisi yang diberlakukan untuk kelas $\mathrm{X}$ (sebelumnya ada materi khusus, namun demikian masih tetap ada materi tentang taat pada aturan yang kemudian diimplementasikan dengan masalah pengelolaan lingkungan), kesadaran siswa khususnya kelas $\mathrm{X}$ yang perlu bimbingan dan motivasi lebih dari

\footnotetext{
${ }^{36}$ Hasil Wawancara dengan Ibu Siti Ana Maryana (Guru PAI SMK Negeri 1 Indramayu Kabupaten Indramayu) pada Hari Sabtu 18 Nopember 2017 Pukul 13.00 WIB. di Ruang Rohis SMK Negeri 1 Indramayu.

${ }^{37}$ Hasil Wawancara dengan Bapak Jenjen Jaeni Dahlan (Kepala Sekolah SMK Negeri 1 Indramayu Kabupaten Indramayu) pada Hari Kamis 16 Nopember 2017 Pukul 09.15 WIB. di Ruang Kepala SMK Negeri 1 Indramayu.

${ }^{38}$ Hasil Wawancara dengan Bapak Rosyidin (Ketua Tim Adiwiyata SMK Negeri 1 Indramayu Kabupaten Indramayu) pada Hari Jum'at 17 Nopember 2017 Pukul 11.20 WIB. di Ruang Guru SMK Negeri 1 Indramayu.
} 


\section{Al-Tarbawi Al-Haditsah: Jurnal Pendidikan Islam}

Vol. 3, No. 2, Desember 2018

guru, karena terkadang masih terbiasa dengan kebiasaan di sekolah terdahulunya yang mungkin penerapan K7-nya tidak seperti di sekolah baru, beda dengan kelas XI dan XII yang sudah mengikuti pembelajaran di SMK Negeri 1 Indramayu lebih lama sehingga mengerti dengan program Adwiyata sekolah, dan tuntutan menyelesaikan materi yang ada di kurikulum Nasional dalam waktu yang disediakan oleh sekolah. ${ }^{39}$

\section{Penutup}

Kebijakan pengelolaan pendidikan berwawasan lingkungan di SMK Negeri 1 Indramayu ini diterapkan dengan adanya fundamental infut yaitu dilihat dari visi, misi, tujuan, motto sekolah yang sudah mencerminkan kepada terdorongnya kesadaran akan penciptaan sekolah yang berwawasan lingkungan, juga dibuktikan secara managerial adanya wakasek bidang kesiswaan, disiplin dan kebersihan lingkungan.

Pembelajaran Pendidikan Agama Islam (PAI) berwawasan lingkungan di SMK Negeri 1 Indramayu mengarahkan aktivitas peserta didik untuk ramah terhadap lingkungan, yang mana aktivitas tersebut meliputi kegiatan Kegiatan Belajar Mengajar dan ekstrakurikuler yang mendukung pendidikan lingkungan hidup sebagai bagian dari pengembangan kurikulum berbasis lingkungan. Sesuai dengan sifat pendidikan lingkungan hidup, SMK Negeri 1 Indramayu menggunakan pendekatan interdisipliner dalam bentuk kurikulum yang terintegrasi dengan lingkungan hidup.

Implementasi pembelajaran Pendidikan Agama Islam (PAI) berwawasan lingkungan di SMK Negeri 1 Indramayu yang diberikan kepada peserta didik, yakni dengan membekali mereka dengan cara dan mengaplikasikannya dalam kehidupan keseharian include di dalamnya tentang penyadaran pentingnya lingkungan hidup. SMK Negeri 1 Indramayu menerapkannya dengan melalui tiga ranah: (a). Mengimplemetasikan PAI berwawasan lingkungan hidup dalam

\footnotetext{
${ }^{39}$ Hasil Wawancara dengan Ibu Siti Ana Maryana (Guru PAI SMK Negeri 1 Indramayu Kabupaten Indramayu) pada Hari Sabtu 18 Nopember 2017 Pukul 13.00 WIB. di Ruang Rohis SMK Negeri 1 Indramayu.
} 
Al-Tarbawi Al-Haditsah: Jurnal Pendidikan Islam

Vol. 3, No. 2, Desember 2018

proses KBM, yang meliputi pengelolaan tujuan pembelajaran, pengembangan materi PAI berwawasan lingkungan, guru dan cara mengajar, siswa dan cara belajar serta pengelolaan evaluasi belajar (b). Pembahasan aspek-aspek dalam implementasi PAI berwawasan lingkungan hidup, dan (c). Metode dalam implementasi PAI berwawasan lingkungan hidup.

Faktor pendukung antara lain: Pendidik dan tenaga kependidikan yang semangat, dan respons peserta didik yang menggembirakan, lingkungan sekolah yang bersih dan asri, dukungan dari orangtua peserta didik di SMK Negeri 1 Indramayu, kerjasama yang baik antar guru dalam menyusun Rencana Pelaksanaan Pembelajaran (RPP) atau monitoring pelaksanan pembelajaran PAI berwawasan lingkungan hidup, fasilitas yang mendukung, dan sudah masuknya program adiwiyata ini ke dalam rencana strategi sekolah.

Sedangkan faktor penghambatnya antara lain: waktu yang terbatas untuk jam tatap muka Pendidikan Agama Islam, adanya perubahan hari efektif belajar, tidak semua materi pembelajaran PAI bisa langsung diintegrasikan kepada wawasan lingkungan, masih ada warga sekolah yang kurang faham akan tujuan sekolah berwawasan lingkungan.

\section{Daftar Pustaka}

Abdilah, Mujiono. 2001. Agama Ramah Lingkungan. Jakarta: Paramadina.

Abdilah, Mulyono. 2005. Figh Lingkungan: Panduan Spiritual Hidup Berwawasan Lingkungan. Yogyakarta: Upp AMP YKPN.

Aly, Hery Noer. 1999. Ilmu Pendidikan Islam. Jakarta: Logos.

Ceballos, Gerardo, Ehrlich, Paul R., Barnosky, Anthony D., García, Andrés, Pringle, Robert M., Palmer, Todd M. 2015. "Accelerated Modern HumanInduced Species Losses: Entering the Sixth Mass Extinction", dalam Science Advances. 1 (5).

Chertow, M.R., 2011. "The IPAT Equation and its Variants", dalam Journal of Industrial Ecology, 4 (4) 2001:13-29.

Creswell, John W. 2016. Penelitian Kualitatif dan Design Research: Memilih di antara Lima Pendekatan. Yogyakarta: Pustaka Pelajar. 
Ghazi, Prince. 2010. The Holy Qur'an and the Environment. The Hashemite Kingdom of Jordan: the Royal al al-Bayt Institute for Islamic Thought.

Hawksworth, David L., Bull, Alan T. 2008. Biodiversity and Conservation in Europe. Springer.

Huesemann, Michael H., and Joyce A. Huesemann. 2011. "Technofix: Why Technology Won't Save Us or the Environment", dalam Chapter 6, "Sustainability or Collapse?" New Society Publishers.

Ilman, David, Joseph Fargione, Brian Wolff, Carla D'Antonio, Andrew Dobson, Robert Howarth, David Scindler, William Schlesinger, Danielle Simberloff, and Deborah Swackhamer. 2011. "Forecasting Agriculturally Driven Global Environmental Change", dalam Science 292.5515: 281-84.

Johnson, D.L., S.H. Ambrose, T.J. Bassett, M.L. Bowen, D.E. Crummey, J.S. Isaacson, D.N. Johnson, P. Lamb, M. Saul, and A.E. Winter-Nelson. 1997. "Meanings of environmental terms", dalam Journal of Environmental Quality, 26: 581-589.

Kutanegara, Pande Made. 2014. Membangun Masyarakat Indonesia Peduli Lingkungan. Yogyakarta: Gadjah Mada University Press.

MacDonald, Glen M. 2010. "Water, Climate Change, and Sustainability in the Southwest", dalam PNAS 107.50: 56-62.

Mangunwijaya, Fachrudin M., Husain Heriyanto, Reza Gholami. 2007. Menanam sebelum Kiama: Islam, Ekologi, dan Gerakan Lingkungan Hidup. Jakarta: Yayasan Obor Indonesia.

Manzoor, S. Parvez. 1991. "Lingkungan dan Nilai-nilai dalam Perspektif Islam", dalam Jurnal Ulumul Qur'an, Nomor 9 Volume 1 Tahun 1991.

Moleong, Lexy J. 2004. Metodologi Penelitian Kualitatif. Bandung: PT. Remaja Rosdakarya.

Nasr, Sayyed Hossein. 2001. Islam dan Nestapa Manusia Modern. Bandung: Pustaka Setia.

Ragab, Ragab, and Christel Prudhomme. 2002. "Soil and Water: Climate Change and Water Resources Management in Arid and Semi-Arid Regions: Prospective Challenges for the 21st Century", dalam Biosystems Engineering. 81.1 (2002): 3-34.

Ramli, Nadjamudin. 2007. Islam Ramah Lingkungan, Konsep dan Strategi Islam dalam Pengelolaan, Pemeliharaan, dan Penyelamatan Lingkungan. Jakarta: Grafindo Khazanah Ilmu.

Sahney, S., Benton, M.J. and Ferry, P.A. 2010. "Links between Global Taxonomic Diversity, Ecological Diversity and the Expansion of Vertebrates on Land", dalam Biology Letters. 6 (4): 544-547. 
Vol. 3, No. 2, Desember 2018

Sihaan, NHT. 2007. Hutan, Lingkungan, dan Paradigma Pembangunan. Jakarta: Pancuran Alam.

Susilo, Rahchmad K. Dwi. 2012. Sosiologi Lingkungan dan Sumber Daya Alam. Yogyakarta: Ar-Ruzz Media.

Thalhah, M. dan Achmad Mufid A.R. 2008. Fiqih Ekologi; Menjaga Bumi Memahami Makna Kitab Suci. Yogyakarta: Total Media.

United Nations General Assembly. 2006. "Report of the Open-Ended Intergovernmental Expert Working Group on Indicators and Terminology Relating to Disaster Risk Reduction", dalam Sustainable Development: Disaster Risk Reduction. Seventy-first session. 1 December 2016.

U.S. Global Change Research Program. 2017. "Highlights of the Findings of the U.S. Global Change Research Program Climate Science Special Report", dalam Executive Summary. Washington, DC.

Pimm, S. L., Jenkins, C. N., Abell, R.; Brooks, T. M., Gittleman, J. L., Joppa, L. N., Raven, P. H., Roberts, C. M., Sexton, J. O. (30 May 2014). "The Biodiversity of Species and their Rates of Extinction, Distribution, and Protection”, dalam Science. 344 (6187): 124. 